School of Business, Economics and Law UNIVERSITY OF GOTHENBURG

\title{
Firm Productivity and Exports: Evidence from Ethiopian manufacturing
}

\author{
Arne Bigsten \\ Mulu Gebreeyesus
}

April 2008

ISSN 1403-2473 (print)

ISSN 1403-2465 (online)

SCHOOL OF BUSINESS, ECONOMICS AND LAW, UNIVERSITY OF GOTHENBURG

Department of Economics

Visiting adress Vasagatan 1,

Postal adress P.O.Box 640, SE 40530 Göteborg, Sweden

Phone + 46 (0)31 7860000 


\title{
Firm Productivity and Exports: Evidence from Ethiopian manufacturing
}

\author{
Arne Bigsten and Mulu Gebreeyesus ${ }^{1}$ \\ Department of Economics \\ University of Gothenburg \\ Box 640 \\ SE 40530 Gothenburg \\ Sweden
}

April 2008

\begin{abstract}
:
This paper examines the causal relationship between exporting and productivity using a ten years long plant-level panel data set from an annual census of Ethiopian manufacturing, rarely available in the sub-Saharan Africa. We exploited its length to trace the trajectory of TFP and other productivity measures of groups of firms classified by their export history. We then tested learning-by-exporting using a onestep system-GMM approach with the export-status included directly in the production function. We addressed potential endogeneity problems by using instrumental variables, and also applied a matching analysis to address potential selection bias. We found strong evidence of not only self-selection but also learning-by-exporting. Depending on the specification previous exporting appears to have shifted the production function by $15-32 \%$. Exporters had on average three times more employees, and paid 1.6 times higher average wage than those of non-exporters.
\end{abstract}

JEL-Classification: F14, O14, D21, L60

Keywords: Productivity, exports, Ethiopia, manufacturing

\footnotetext{
${ }^{1}$ Thanks for good advice to Måns Söderbom and Rick Wicks. .
} 


\section{Introduction}

Most countries in sub-Saharan Africa (SSA) gained independence in the early 1960s, and they generally chose an import-substitution industrialization strategy. Initially it seemed to work, but once the easy substitutions had been made the inefficiencies associated with protectionism became apparent. In the 1980s many countries introduced structural-adjustment programs, with a gradual reduction of the levels of protection, and even outright export-promotion measures. It was expected that the increased openness to international trade would increase efficiency and economic growth, because firms that export benefit from exposure to foreign technology, while larger markets and competition and larger markets would make it possible for them to exploit economies of scale and improve their productivity.

A number of studies have shown that exporters and non-exporters are quite different. Exporters are larger, more capital-intensive, pay higher wages, and are more productive than non-exporters (Clerides, Lach, and Tybout, 1998; Delgado, Farinas, and Ruano, 2002; Kraay, 1999; Aw, Chung, and Roberts, 2000; Bigsten et al., 2004; and Van Biesebroeck, 2005). These characteristics of exporters could be either a cause or a consequence (or both) of their participation in the export market.

There are two competing hypotheses in the literature with regard to the relation between exporting and productivity - self-selection versus learning-by-exporting. Self-selection asserts that firms which became exporters were more productive to start with and were thus more able to enter the export market. Firms that export incur additional costs, perhaps to modify domestic products for foreign consumption, for transportation, distribution, or marketing, or for skilled personnel to manage foreign networks. These costs are entry-barriers that more-productive firms were more likely to be able to cope with (Roberts and Tybout, 1997, Bernard and Jensen, 1999). Export markets are also likely to be more competitive than domestic markets, making it harder for less-productive firm to overcome these barriers. Firms might even be forward-looking with the desire to export leading them to improve productivity so as to become competitive in foreign markets. Thus, there might be prior productivity differences between exporters and non-exporters (Wagner, 2007).

Learning-by-exporting, on the other hand, asserts that even if there is selfselection, exporters also improve productivity because of entering foreign markets, which increases the competitive pressures on them, while also enabling them to 
exploit economies of scale. Firms which enter the international market are also more likely to acquire new technology. The two hypotheses are thus by no means mutually exclusive: High-productivity firms, that can afford the extra cost of entry into export markets, may still improve their productivity as a result of exporting (Fernandes and Isgut, 2004).

Following the influential papers by Bernard and Jensen (1999) and Clerides, Lach, and Tybout (1998) there has been growing interest in testing the causal relationship between exporting and productivity. Most studies have found evidence supporting self-selection but not learning-by-exporting (e.g. Bernard and Jensen, 1999, for the USA; Clerides, Lach, and Tybout, 1998, for Colombia, Mexico and Morocco; Arnold and Hussinger, 2004, for Germany; Delgado, Farnas and Ruano, 2002, for Spain; and Aw, Chung, and Roberts, 2000, for Taiwan). However, some studies have found evidence of both self-selection and learning-by-exporting (Hahn, 2004, for Korea; Fernandes and Isgut, 2004, for Colombia; Kraay, 1999, for China; and Girma, Greenaway, and Kneller, 2004, for the UK; and Bigsten et al., 2004, as well as Van Biesebroeck, 2005, for SSA countries). Hence the evidence is mixed, which might indicate that the effects vary by economic environment. For example, exporting may have less effect on productivity in a highly industrialized country, where differences between exporting and non-exporting firms may be small.

The empirical evidence in Sub-Saharan Africa is meager, partly because of the lack of longer panel-data. Thought they differ in the number of countries included (four and seven), the only two studies, Bigsten et al. (2004) and Van Biesebroeck (2005), both studies use the same data-source, a firm survey done by the Regional Program of Enterprise Development (RPED) in the 1990s, covering only three years, making it hard to identify a learning-effect. Longer panel-data might provide stronger evidence.

This study examines the causal relationship between exporting and productivity and adds to the literature in several ways. First, we used ten years of plant-level paneldata from an annual census of Ethiopian manufacturing firms with at least 10 employees. Such long panels are rarely available. Second, we present trajectories of productivity in extended pre- and post-export entry periods for groups with different export histories and examine the pre- and post-entry behavior of exporters with regard to investment activity, employment, and sales. Third, we apply a matching analysis to 
address selection bias in addition to controlling unobserved heterogeneity with general method of moments (GMM).

The next section presents the background and discusses the data. Section three then reviews methodological issues and recent results, and briefly sketches our empirical strategy. Section four reviews the performance of exporters and nonexporters over time, while section five provides the results from our regression analysis, controlling for unobserved heterogeneity and selection-bias. Section six summarizes the main findings and draws conclusions.

\section{Background, data, and basic statistics}

After the fall of the Dergue government in 1991 Ethiopia adopted a structural adjustment program similar to those that other African countries had pursued through the 1980s, including trade liberalization. In 1993, the new government initiated a comprehensive trade reform aimed at dismantling quantitative restrictions and gradually reducing the level and dispersion of tariff rates. Trade liberalization was accompanied by financial market liberalization and a large devaluation of the currency (Birr). Recently the government has increased the policy emphasis on export-led manufacturing growth, providing a wide range of incentives to promote exports. Textiles, leather, and agro-processing are the sectors that the government has most sought to promote. The 2001 Export Trade Duty Incentive Scheme included duty draw-backs, vouchers, and bonded manufacturing warehouses, whereby exporters are refunded $100 \%$ of any duty paid on raw materials. To further encourage exporters to acquire foreign technology and expertise, the government also issued directives in 2004 to reduce taxes and other costs on salaries paid to foreign experts.

Ethiopia still has a small industrial base, even by African standards. Table 1 shows the industry and manufacturing shares of GDP and the manufacturing share of merchandise exports of Ethiopia and sub-Saharan Africa as a whole. Ethiopia's industry share of GDP increased only from $10.7 \%$ in 1996 to $13.3 \%$ a decade later, much lower than sub-Saharan Africa (31.8\%). Ethiopia's manufacturing share of GDP also remains very low (5.1\%), again far less than the SSA, although the SSA numbers are somewhat distorted by the inclusion of South Africa, the single most industrialized country in the region. Ethiopian exports in 2005 were mainly food (62 
$\%$ ) and raw materials (26\%), while the manufacturing share of merchandize exports was only $11 \%$.

$<$ Table 1 about here $>$

The data used here was collected by the Ethiopian Central Statistic Agency (CSA). The 10-year unbalanced panel comprises 7870 firm/year observations. Between 1996 and 2004 Ethiopian manufacturing grew at an average rate of $6 \%$ (Table 2). Output also grew by an annul average over $6 \%$ in the same period, though highly variable. Employment growth was less than $2 \%$, however. Manufacturing was dominated by smaller firms, with highly-skewed size-distribution revealed by the big gap between mean employment (123) and the median (26).

$<$ Table 2 about here $>$

Table 3 shows export-participation and percent of exports in total production by industry. Overall, less than $5 \%$ of manufacturing firms exported. The percent of exports in total manufacturing was less than $8 \%$. Among exporting firms about $32 \%$ of production was exported.

As noted, export participation varied enormously by industry: $88 \%$ of manufacturing exports were concentrated in leather, textiles, beverages, garments, footwear, and food, in that order. Leather declined from over $91 \%$ of all manufacturing exports in 1996 to $68 \%$ in 2005, while food and textiles picked up the slack. These six industries also accounted for $62 \%$ of formal manufacturing employment and $54 \%$ of formal manufacturing output. Therefore the other industries are excluded from the rest of the analysis.

$<$ Table 3 about here $>$

In 2005 CSA started sampling rather than taking a census for some industries, for example bakery products. The number of bakeries (in the food industry) therefore, declined in the data in 2005. As a matter consistency, and since bakeries export very little, we excluded them in all years from the remaining analysis, which was thus based on 2250 firm/year observations. 
The annual CSA census includes questions on output, sales (domestic and exports), inputs and costs, employment, wages, other labor-costs, investment, etc. To estimate productivity we constructed series of inputs and output. Gross output was deflated by industrial output-deflators for each two-digit industrial classification. Intermediate input-cost were taken as the sum raw materials, transport, and energy costs. In the absence of a sectoral input deflator, we used the GDP-deflator for raw materials, and for electricity the official electricity deflator; but for oil and transport costs we constructed a deflator from the reported volume and value of oil used.

The data provides beginning-of-the-year capital, investments, assets sold if any, and year-end capital for each firm and year. But for the sake of consistency we constructed a new series of capital stock using the perpetual inventory method. Capital-stock was calculated as, $K_{i t}=K_{i t-1}+\frac{I_{t}}{p^{t}}-\delta K_{i t-1}-s K_{i t}$ where $K_{i t-1}$ denotes the beginning-year capital; $\mathrm{p}^{\mathrm{t}}$ the investment-deflator; $\delta$ depreciation rate; and $\mathrm{sK}_{\mathrm{it}}$ assets sold in year $\mathrm{t}$. Thus for each firm we took the beginning-year capital (when it entered the data set) as a base and constructed capital-stock sequentially by adding investment and subtracting assets sold and depreciation. We used different depreciation rates for different types of assets; $8 \%$ for machinery and equipment; $5 \%$ for buildings; and 10 $\%$ for vehicles and for furniture and fixtures. Then we derived a new capital-stock series $(\mathrm{K})$ by taking the average of the beginning and year-end capital-stock.

Labor was measured as the sum of permanent and temporary workers, the latter adjusted to year-equivalent labor. However, to account for the quality-difference of labor in the production-function estimations, we constructed a labor quality index using the average wage differential between production workers, non-production workers, and seasonal workers.

\section{Firm productivity and exporting: Methodological issues and recent results}

There are two broad approaches to the analysis of the relation between exporting and productivity. One is to separate firms into exporters and non-exporters and assess the differences in productivity. The other is to test the effect of previous exporting in a firm-productivity regression that includes other explanatory variables. There are a number of extensions to each approach, briefly reviewed below. Bigsten and Söderbom (2006) and Wagner (2007) review recent results. 
To examine self-selection into exporting among US manufacturers Bernard and Jensen (1999) estimated at two points in time the impact of previous performance (some years back) on the current export status. They also examined performance by firm- classification: always exported; started exporting; stopped exporting; switched back and forth; and never exported. Using a 5-year window, they found that those who started exporting began with higher productivity than those who never exported. but lower than those who always exported. However, the productivity of those who started exporting rose before, and especially during, the year they began exporting.

Using the same method for Korean manufacturing, Hahn (2004) also found evidence of both self-selection and learning-by-exporting. Already several years before they began to export, plants that started exporting had higher TFP than did those that never exported, and they then widened the TFP-gap from those that never exported, while closing the gap to those that always exported. However, the learning effect is most pronounced immediately after entry into the export market. Fernandes and Isgut (2004) used the same method for Colombian manufacturing but with a seven-year window. They found a permanent jump in TFP when firms started to export and productivity growth remained positive up to four years later.

A source of continuous debate with regard to the other approach, firm productivity-regressions, is how to derive consistent and unbiased estimates of TFP. Some studies have actually used a productivity-index that takes factor-shares of inputs as weights without regressing at all (e.g., Aw, Chung, and Roberts, 2000, for Taiwan and Korea; Hahn, 2004, for Korea; and Delgado, 2002, for Spain). This indexapproach relies on assumptions that all markets are competitive, that factors are paid their marginal productivity, and that returns to scale are constant, among others. These are very restrictive assumptions, particularly for Africa (Söderbom and Teal, 2000). ${ }^{2}$

But for those who derived TFP by regressing a production function, a major challenge is how to address the endogeneity that might arise from correlation between unobserved on productivity and inputs. Various methods have been developed, including a semi-parametric approach proposed by Olley and Pakes (1996), and a

\footnotetext{
${ }^{2}$ Clerides et al. (1998) use average variable cost as measure of efficiency in a related study of learning-by-exporting effect on three countries (Colombia, Mexico and Morocco). Others have also used labor productivity and efficiency scores derived from frontier models.
} 
GMM approach by Blundell and Bond (1998). ${ }^{3}$ Using an instrumental variable method in the two-step approach, where one first estimates the production function and then the productivity equation, does not address the endogeneity problem, because endogeneity might also arise due to omitted variables. If export participation is endogenous because it is positively associated with productivity then regressing the production function will yield inconsistent input-coefficients and productivityestimates. A one-step approach where export status is directly included in the production function might reduce the bias. Van Biesebroeck (2005), Bigsten et al. (2004), and Fernandes and Isgut (2004) thus used GMM to estimate a one-step approach, and all found evidence of both self-selection and learning-by-exporting.

Clerides et al. (1998) proposed joint estimation of the productivity-equation and export-participation equation, because if there is unobserved heterogeneity affecting both productivity and the probability of exporting, a single-equation model might yield a spurious positive relation. Clerides et al. (1998), Bigsten et al. (2004), and Van Biesebroeck (2005) used the full-information-maximum-likelihood (FIML) estimation method where standard errors from both equations are assumed to be i.i.d normal. Bigsten et al. (2004) pointed out, however, that this assumption is potentially restrictive and therefore adopted a non-parametric strategy for characterizing the distribution of random effects.

Wagner (2002), Girma et al. (2004) and Arnold and Hussinger (2004) used a somewhat different approach, the matching-method from labor economics to control more precisely for differences between the "treatment" and the "control" groups. This approach addresses the problem that arises if the treated units (in this case exporters), are not selected randomly from a population but are selected or self-selected according to certain criteria, so that, here, the effect cannot be evaluated simply by comparing the average productivity of exporters and non-exporters. In this approach, each exporter is matched to an untreated unit that is as similar as possible before treatment. Girma et al. (2004) found evidence of learning-by-exporting for UK

\footnotetext{
${ }^{3}$ Olley and Pakes (1996) proposed a semi-parametric approach using observable micro information, for example investment, as a proxy to control for the part of the error correlated with inputs. Levinsohn and Petrin (2003) extended this approach by introducing the possibility of using intermediate inputs as a proxy rather than investment. Ackerberg and Caves (2003) and Bond and Soderbom (2004) criticized the proxy method, on the basis of the problems of identifying the parameters.
} 
manufacturers, while Wagner (2002) found only weak effects, and Arnold and Hussinger (2004) found no significant effects of learning for German manufacturers.

We used a combination of the two broad methods reviewed above. First, following Bernard and Jensen (1998), we exploited the long-panel nature of our data by comparing the productivity pattern of groups of firms by their export-history in a five-year window. We used not only TFP derived from a production function, but also labor productivity and labor cost per unit of output. We report the pre- and post-entry export behavior of firms with regard to investment, employment, and sales by different export participation histories.

Then in section five we used a one-step approach, with export status included directly in the production function. Following Blundell and Bond (1998), we used an instrumental-variables approach, specifically system-GMM, to control for endogeneity. Then, following Wagner (2002) and Girma et al. (2004), again using system-GMM, we used matching to control for selection bias.

\section{Performance of exporters versus non-exporters}

\subsection{Exporters do better - export-premia}

As has been found in many other studies, we also found that exporters' performance is much better than non-exporters' by various measures. Table 4 compares the average of certain indictors such as employment, average wages of production and nonproduction workers, capital per worker and output per worker of exporters and nonexporters by industry. Generally, exporters had more workers, paid higher wages for both production and non-production workers, had more capital per worker, and produced more output per worker. On average exporters were three times bigger in terms of employment, paid 1.6 times higher wages to workers, and produced 1.6 times more output per worker. These differences are similar to those reported for subSaharan Africa in Van Biesebroeck (2005).

$<$ Table 4 about here $>$

To test for export-premia we ran regressions of the different performance measures on export status with and without controls. We estimated

$$
\ln Y_{i t}=\alpha_{0}+\beta \text { Export }_{i t}+\gamma \text { Control }_{i t}+e_{i t}
$$


where $Y_{\text {it }}$ represents various measures of current performance (TFP (derived from production-function estimation by two-digit ISIC classification; for details see Appendix A), labor productivity (Q/L), value added per labor (VA/L), employment, capital intensity (K/L), and average wage of production and non-production workers); Export is a dummy variable for current export status ( 1 if export in year $t$; otherwise 0); and Control includes dummy variables for industry, year, and size of the firm.

Table 5 shows the results. Even after controlling for industry, year, and size, exporters performed better than non-exporters, and all differences were highly significant. Wages were 33-35\% higher; output per labor was $22 \%$ more; and TFP was $28 \%$ higher. These results are consistent with earlier findings.

$<$ Table 5 about here $>$

\subsection{The trajectory of productivity}

A possible problem with the estimation above is that all the exporters are treated equally, regardless of whether they were always exporting, newly exporting, stopped exporting, or switched back and forth. To understand the dynamics of productivitychanges better, we classified firms into these groups:

Always exporting = firms that were exporting at the beginning of the sample period and continued exporting through the end (2005)

Newly exporting $=$ firms that began exporting during the sample period (possibly new firms entirely).

Switchers $=$ firms that changed their status more than once

Never exporting $=$ firms that never participated in exports

We test the self-selection and learning by exporting hypotheses using the following equation proposed by Bernard and Jensen (1999):

$$
\ln Y_{i t}=\sum_{g \in G} \sum_{k \in K} \beta_{g k} D_{g i} D_{k i}+\text { Controls }+\varepsilon_{i t}
$$

where $\mathrm{Y}$ is a measure of firm performance; $\mathrm{G}$ is the set of four plant groups (always, entrant, switchers, and never exporting); and $\mathrm{K}$ is the set of locations in the five years window so that $\mathrm{K}=\{-2,-1,0,1,2\} . \mathrm{D}_{\mathrm{g}}$ and $\mathrm{D}_{\mathrm{k}}$ are dummy variables denoting plant group and location in the five years window, respectively. Thus, the coefficient $\beta_{\mathrm{gk}}$ 
denotes the mean value of each group $\mathrm{g}$ at each location $\mathrm{k}$. The control variables were again industry, year, employment size, plus age.

We use three different measures of firm performance - TFP, labor productivity $(\mathrm{Q} / \mathrm{L})$ and unit labor cost (ULC) - as dependent variables in separate estimations, all in levels. Equation 2 was estimated with the never exporting at period (-2) as control category. Using period (2) instead yielded similar patterns, with only some changes in scale. In all estimations we control for industry, year, and age effects. In addition we have controlled for size effects in the TFP estimation. Table B1 in the Appendix B shows the full results.

In general, those always exporting, newly exporting, and switchers performed better than those never exporting on all three measures. Even before they began exporting, new exporters were better then those never exporting and they continued to widen the gap while converging and sometimes overtaking those always exporting. Almost all their post-entry coefficients are significant at least at the $10 \%$ level.

Figure 1 shows changes in productivity before and after those newly exporting began to export, compared to those never exporting. Those newly exporting had higher TFP at least one-year before they started exporting (panel a). They continuously increased their TFP throughout the given period with a marked jump when they began exporting. Similarly, those newly exporting had higher labor productivity and lower unit labor costs even before starting to export, and continued to improve, relative to those never exporting, at least during the fist year after entry.

$<$ Figure 1 about here $>$

The fact that, even before they began to export, entrants' productivity was higher than that of non-exporters, is consistent with earlier findings (Bernard and Jensen, 1999; Hahn, 2004; Fernandes and Isgut, 2005) and supports the hypothesis of selfselection. The productivity of entrants was also found to increase in the post-export period (at least during the following year), and to remain higher, with a widening gap from those never exporting. This is evidence of learning-by-exporting. 


\subsection{Adjustments firms made before and after beginning to export}

Exporting might help overall industrial expansion. How do exporters behave in terms of investment, employment, and sales before and after beginning to export, and how does it differ from non-exporters? Following Bernard and Jensen (1999), we estimated Equation (2) with employment, investment, and sales (all in levels) as dependent variables using a 5-years window, while controlling for industry, year, and age (full estimation results in Table B2 in Appendix B).

Firms that never exported were far below all other groups in employment, investment, and sales, with a declining pattern except in the fifth year (Figure 2). Firms that always exported were above all other groups, but with a declining pattern. Newly exporting firms, however, were far above those who never exported with a rising trend in all measures.

$<$ Figure 2 about here $>$

Investment grew slightly overall, with a peak in the year of entry (panel $2 b$ ). newly exporting firms had many more employees, than those who never exported, but their employment fell overall after a peak in the year of entry (panel 2c). Overall, the biggest changes were in investment, especially during the year of entry, presumably as these intending to export prepared to do so. Sales rose slightly while employment fell slightly overall, again indicating increasing productivity.

\section{Did exporting improve productivity? Controlling for unobserved heterogeneity and selection bias}

\subsection{Controlling for unobserved heterogeneity}

We estimated a Cobb-Douglas production function specification with three factors.,

$$
Y_{i t}=A_{i t} K_{i t}^{\beta_{k}} L_{i t}^{\beta_{l}} M_{i t}^{\beta_{m}}
$$

where $\mathrm{Y}$ is output and $\mathrm{A}$ is total factor productivity (TFP); $\mathrm{K}, \mathrm{L}$, and $\mathrm{M}$ are capital, labor, and intermediate inputs. A logarithmic transformation of Equation (3) yields

$$
y_{i t}=\beta_{k} k_{i t}+\beta_{l} l_{i t}+\beta_{m} m_{i t}+a_{i t}+v_{i t},
$$

where lower case indicates logs of the same variables, and $v_{i t}$ is a pure random error that is unknown to both the firm and the econometrician. 
Total factor productivity $\left(\hat{a}_{i t}\right)$ is hypothesized to depend, among others things, on whether or not the firm was exporting in the previous year.

$$
\hat{a}_{i t}=\delta_{k} \text { exports }_{i, t-1}+\gamma Z+\eta_{i t}+\varepsilon_{i t}
$$

where $\mathrm{Z}$ denotes control variables; $\eta_{i t}$ firm specific aspect of productivity; and $\varepsilon_{i t}$ is a pure random error.

The usual practice is a two-step estimation, with TFP first derived from Equation (4) and then estimated on prior exporting status and other controls with Equation 5. However, the correlation between the factors and a possible unobserved effect that includes productivity might affect the coefficients of the factors, thus biasing the TFP derived. The endogeneity problem that might arise from unobserved heterogeneity can be corrected using instrumental variables as in the recently developed system-GMM approach by Blundell and Bond (1998).

However, there is another source of endogeneity which might not be solved in this two-step framework. If export-status is correlated with inputs, then omitting the export-dummy from the production-function regression could yield inconsistent inputcoefficients and productivity-estimates. In that case a one-step approach with the export-status directly included in the production function might reduce the bias. Substituting Equation (5) into (4) and, following Van Biesbroeck (2005), assuming that productivity evolves according to an autoregressive process yields the dynamic model

$$
y_{i t}=\lambda y_{i t-1}+\beta_{k} k_{i t}+\beta_{l} l_{i t}+\beta_{m} m_{i t}+\delta \operatorname{exports}_{i, t-1}+\gamma Z+\eta_{i t}+v_{i t},
$$

The variable of interest is the prior export-status. If $\delta$ turns out to be positive and significant, learning-by-exporting would seem to be occurring.

Using an export-dummy indicating only participation might not adequately capture the learning effects, however. Not all exporters have the same engagement in export markets. While some devote considerable resources to exporting, others - only marginally involved with little scope for learning - would probably generate a downward bias in the estimated learning-by-exporting effect (Fernandes and Isgut, 2004). Following Fernandes and Isgut, we included two variables capturing export experience and production experience in a separate estimation. Export experience is defined here as the number of years the firm had exported up to $t-1$. Unfortunately data on experience was available only within the sample period, so a firm that exported in 1996 was counted as having one year of export-experience in 1997. 
Production-experience was approximated by age of the firm. In all estimations we included year- and industry-dummies to control for any macro-cyclical effects or industrial differences.

The system-GMM method used to estimate Equation (6) combines the lagged levels of regressors and the dependent variable as instruments for the first-difference equation, and the first differences as instruments for the equation in levels. After experimentation with different instrumentations, we report the results that have passed the necessary tests in Table (6). First lag and earlier were used as instruments for all the inputs for the differenced equation, second lag and earlier for output and the other explanatory variables. On the other hand, only lagged first-differences were used as instruments for the level equations. The null hypothesis that the instruments are valid was not rejected using the Hansen test, which is robust for two-step estimation. We found no evidence of second-order serial correlation.

The first column of Table 6 shows the basic results: The export-dummy is positive and significant, suggesting that previous exporting increased current productivity. The coefficient remained significant when export- and production-experience were included, (column 2). Thus, exporting in the previous year appears to have shifted the production function $15-17 \%$. Neither export-experience nor firm age was significant in this framework.

As a robustness-check we also estimated the two-step approach with the derived TFP from Equation (4) used as dependent variable in estimating Equation (5), again using system-GMM. In addition to the one-year lagged export dummy, the model included lagged TFP, capital-intensity, firm age, and export-experience. Again, consistent with the learning-by-exporting hypothesis, previous exporting affected productivity positively and significantly. The results are not reported here to save space.

\subsection{Addressing selection bias via matching}

The most recent innovation in assessing learning-by-exporting through groupcomparisons, often used in the empirical labor market literature, is matching. Identifying the effect of treatment (exporting) by simply comparing the treated and control (non-exporting) groups using all observations may be inappropriate. ${ }^{4}$ Because

\footnotetext{
${ }^{4}$ Rosenbaum, and Rubin (1983) discusses the advantage of using matching method.
} 
selection into the exporting group is non-random, meaning that exporters may have very different characteristics from non-exporters. A better comparison would, thus be between exporters and the non-exporters with similar characteristics. When matching we select from the non-exporters those whose variables are as similar are as similar as possible to the exporters' (Girma et al. 2004).

We need first to identify those variables that make a firm more likely to export. Size, capital-intensity, firm age, productivity, and type of ownership have been found to affect the probability of exporting (Roberts and Tybout, 1998; Bigsten et al. 2004; Arnold and Hussinger 2004). Hence, using psmatch2 in Stata 9 (Leuven and Sianesi, 2003) we first estimated the probability of exporting (the "propensity score") using the following export participation equation

$$
\mathrm{EX}_{\mathrm{it}}=\ln (\text { Size })_{\mathrm{it}-1}+\ln (\mathrm{K} / \mathrm{L})_{\mathrm{it}-1}+\ln (\text { Age })_{\mathrm{it}-1}+\ln (\text { Age })_{\mathrm{it}-1}^{2}+\text { State }+\mathrm{IND}+\text { year }+\varepsilon_{i t}
$$

Where EX is another export-dummy, equal to one if the firm exported in year $t$, and zero otherwise. Size is the number of workers. K/L is capital-intensity, the ratio of capital to number of employees. Firm age is again the number of years since establishment. State is a dummy equal to one if state-owned, and zero otherwise. We also controlled for industry (IND) and year in all estimations.

The propensity score was estimated with a logistic model, $\mathrm{k}=5$ nearest-neighbors matching, and common support conditions imposed. All but 14 of the exporting firms were matched with similar non-exporters. This was because of our imposition of common support that drops exporters whose pscore is higher than the maximum or less than the minimum pscore of the controls. A total of 388 non-exporting observations were assigned as matches to the 266 exporting observations.

Size of the firm, age, capital-intensity, and being state owned all had significant positive effects on export-participation (Table B3 in Appendix B). Age had a concave relation with export participation. In the psmatch2 estimation (Table B4 in Appendix B). the TFP of exporters was higher than that of non-exporters, and this difference is significant in both unmatched and matched samples. Thus, even controlling for selection-bias exporters had higher productivity than non-exporters.

We tested the causal relation from exporting to productivity by estimating Equation (6) again based on the matching sample. After experimentation with different instrumentations, we report the results that passed the necessary tests in 
Table (6), column 3. ${ }^{5}$ Previous exporting had a significant positive effect of about 32 $\%$, twice the magnitude found in the estimation using all observations. Hence the matching estimation provides even stronger evidence of learning-by-exporting in Ethiopian manufacturing. The number of years exporting also had a positive effect at the ten percent level, providing some evidence of accumulated learning.

\section{Summary and concluding remarks}

The main aim of this paper has been to examine whether there has been learningfrom-exporting in the case of Ethiopian manufacturing. We used ten years of censusbased panel-data and exploited its length to trace the trajectory of TFP and other productivity measures of groups of firms classified by their export history. We then tested learning-by-exporting using a one-step system-GMM approach with the exportstatus included directly in the production function. We addressed the potential endogeneity problem by using instrumental variables, and also applied a matching analysis to address potential selection bias.

Exporting firms were generally more productive than non-exporters, and even prior to their entry into the export market. New exporters were also more productive than those who never exported. New exporters exhibited a surge of productivity in the year of entry, and continued to increase their productivity afterwards. This is evidence of both self-selection and learning-by-exporting.

In our explicit test of previous exporting in a production framework controlling for unobserved heterogeneity, we found further evidence of learning-by-exporting in Ethiopian manufacturing, even stronger when using the matched sample. Depending on the specification previous exporting appears to have shifted the production function $15-32 \%$.

Unlike other groups, new exporters increased capital investment and sales both before and after entry, with a remarkable jump in the year of entry. This suggests that new exporters made a conscious decision to upgrade their scale and quality of operations.

\footnotetext{
${ }^{5}$ Twice lag and earlier of all variables in the right hand side except raw materials are used as instruments for the differenced equation. On the other hand, only the lagged first differences are used as instruments for the level equations. The null that the instruments are valid is not rejected using the Hansen test which is robust for two-step estimation. We have also found no evidence of second order serial correlation.
} 
Exporters were not only more productive than non-exporters, but also had on average three time more employees They also paid on average wages 1.6 times higher than those of non-exporters, for both production and non-production workers. Despite these desirable characteristics, only $5 \%$ of manufacturing firms were participating in the export market. Size and state-ownership were the most important factors determining export-participation. This suggests that some potential exporters face barriers to exporting. Especially since there are learning-by-exporting externalities, there are good grounds for policy-makers to intervene to reduce the barriers. The export-oriented measures just introduced in Ethiopia seem sensible, but the government should also support critical export infrastructure, such as the customs service, and the administration of taxation. The regulation of production has to be brought up to international standards. Ethiopia has a very long way to go before the economy is truly integrated with the world economy, but the evidence of learning-bexporting found here suggests a way forward. 


\section{References}

Ackerberg, D. A., and K. Caves (2003), "Structural Identification of Production Functions," Department of Economics, UCLA, mimeo.

Arnold, J., and K. Hussinger (2004), "Export Behavior and Firm Productivity in German Manufacturing: A Firm-level Analysis," Discussion Paper No. 04-12, Centre for European Economic Research (ZEW).

Aw, B., S. Chung, and M. Roberts (2000), "Productivity and Turnover in the Export Market: Micro-Level Evidence from the Republic of Korea and Taiwan (China)," World Bank Economic Review 14(1): 65-90.

Bernard, A.B., and J.B. Jensen (1999), "Exporting and Productivity”, NBER Working Paper 7135, Cambridge MA.

Bigsten, A., P. Collier, S. Dercon, M. Fafchamps, B. Gauthier, J. Gunning, A. Oduro, R. Oostendorp, C. Pattillo, M. Söderbom, F. Teal, and A. Zeufack (2004), "Do African Manufacturing Firms Learn from Exporting?," Journal of Development Studies 40(3): 115-141.

Bigsten, A. and M. Söderbom (2006), "What Have We Learned from a Decade of Manufacturing Enterprise Surveys in Africa?," World Bank Research Observer, 21(2): 241-65.

Blundell, S., and S. Bond (1998), "Initial Conditions and Moment Restrictions in Dynamic Panel Data Models," Journal of Econometrics 87 (1), 29-52.

Bond, S., and M. Söderbom (2004), "Adjustment Costs and the Identification of Cobb Douglas Production Functions," Centre for Studies of African Economies, Oxford University.

Clerides, S., S. Lach, and J. Tybout (1998), "Is Learning-by-Exporting Important? Micro-Dynamic Evidence from Colombia, Mexico, and Morocco," Quarterly Journal of Economics 113(3): 903-47.

Delgado, M., J. Fariňas, and S. Ruano (2002), "Firm Productivity and Export Markets: A Non-Parametric Approach," Journal of International Economics 57(2): 397-422.

Fernandes, A. M., and A. E. Isgut (2005), "Learning-by-Doing, Learning-byExporting, and Productivity: Evidence from Colombia," Working Paper 3544, World Bank.

Girma, S., D. Greenaway, and R. Kneller (2004), "Does Exporting Increase Productivity? A Microeconometric Analysis of Matched Firms," Review of International Economics 12(5), 855-866.

Hahn, C. (2004), "Exporting and Performance of Plants: Evidence from Korean Manufacturing", NBER Working Paper 10208, Cambridge MA..

Kraay, A. (1999), "Exportations et Performances Economiques: Etude d'un Panel d'Entreprises Chinoises," Revue d'Economie du Developpement 0(1-2): 183207.

Leuven, E., and B. Sianesi (2003), "PSMATCH2: Stata module to perform full Mahalanobis and Propensity Score matching, common support graphing, and covariate imbalance testing," Boston College Department of Economics, Statistical Software Components. http://ideas.repec.org/c/boc/bocode/s432001.html

Levinsohn, J. and A. Petrin (2003), "Estimating Production Functions Using Inputs to Control for Unobservables," Review of Economic Studies 70(2), 317-341.

Olley, G. and A. Pakes (1996), "The Dynamics of Productivity in the Telecommunications Equipment Industry," Econometrica 64(6), 1263-1297. 
Roberts, M., and J. Tybout (1997), "The Decision to Export in Colombia: An Empirical Model of Entry with Sunk Costs," American Economic Review 87(4):.545-64.

Rosenbaum, P.R, and Rubin, D.B. (1983), "The Central Role of Propensity Score in Observational Studies for Causal Effects," Biometrika 70(1): 41-55.

Söderbom, M., and F. Teal (2000), "Skills, Investment and Exports from Manufacturing Firms in Africa," Journal of Development Studies 37(2): 13-43.

Van Biesebroeck, J. (2005), "Exporting Raises Productivity in Sub-Saharan African Manufacturing Plants," Journal of International Economics 67(2): 373-391.

Wagner, J. (2002), "The Causal Effect of Exports on Firm Size and Labor Productivity: First Evidence from a Matching Approach," Economics Letters 77(2), 287-92.

Wagner, J. (2007), "Export and Productivity: a survey of the evidence from firm level data," The World Economy, 30(1): 60-82.

Windmeijer, F., (2000), “A Finite Sample Correction for the Variance of Linear Twostep GMM Estimators,” Working Paper 00/19, The Institute for Fiscal Studies, London:

World Bank (2007), World Development Indicators 2007, CD-Rom, Washington DC. 


\section{Tables and figures}

Table 1: Industry and manufacturing shares of GDP, and manufacturing shares of merchandise exports, for Ethiopia and SSA, 1996-2005.

\begin{tabular}{|c|c|c|c|c|c|c|}
\hline \multirow[b]{2}{*}{ Year } & \multicolumn{2}{|c|}{$\begin{array}{l}\text { Industry, value added } \\
\text { (\% of GDP) }\end{array}$} & \multicolumn{2}{|c|}{$\begin{array}{l}\text { Manufacturing, value } \\
\text { added (\% of GDP) }\end{array}$} & \multicolumn{2}{|c|}{$\begin{array}{l}\text { Manufactures exports } \\
\text { (\% of merchandise } \\
\text { exports) }\end{array}$} \\
\hline & Ethiopia & SSA & Ethiopia & SSA & Ethiopia & SSA \\
\hline 1996 & 10.3 & 31.0 & 5.1 & 14.0 & NA & 28.6 \\
\hline 1997 & 11.0 & 30.2 & 5.2 & 14.0 & 9.6 & 30.2 \\
\hline 1998 & 12.3 & 28.5 & 5.1 & 13.8 & 6.8 & 29.4 \\
\hline 1999 & 12.8 & 28.9 & 5.6 & 13.4 & 6.7 & 29.7 \\
\hline 2000 & 12.4 & 31.3 & 5.7 & 13.3 & 9.8 & 28.4 \\
\hline 2001 & 13.3 & 30.7 & 6.0 & 13.3 & 13.4 & 33.5 \\
\hline 2002 & 14.5 & 30.7 & 6.0 & 13.6 & 14.3 & 37.4 \\
\hline 2003 & 14.1 & 30.8 & 5.6 & 13.3 & 11.4 & 33.2 \\
\hline 2004 & 13.5 & 31.6 & 5.3 & 14.3 & NA & NA \\
\hline 2005 & 13.3 & 31.8 & 5.1 & 14.0 & NA & NA \\
\hline
\end{tabular}

Source: World Development Indicators (WDI), 2007

Table 2: Number of establishments, employment, and output in the formal manufacturing sector, 1996-2005

\begin{tabular}{|c|c|c|c|c|c|c|}
\hline \multirow[b]{2}{*}{ Year } & \multirow[b]{2}{*}{$\begin{array}{c}\text { Number of } \\
\text { firms }\end{array}$} & \multicolumn{2}{|c|}{ Number of workers } & \multicolumn{3}{|c|}{ Growth of the manufacturing sector } \\
\hline & & Mean & median & $\begin{array}{l}\text { Number of } \\
\text { firms }\end{array}$ & $\begin{array}{c}\text { Employ- } \\
\text { ment }\end{array}$ & Output \\
\hline 1996 & 623 & 146.3 & 23 & & & \\
\hline 1997 & 703 & 136.5 & 23 & 12.8 & 5.4 & 2.0 \\
\hline 1998 & 725 & 128.6 & 22 & 3.1 & -2.9 & 17.4 \\
\hline 1999 & 737 & 137.8 & 23 & 1.7 & 8.9 & -0.5 \\
\hline 2000 & 735 & 125.0 & 26 & -0.3 & -9.5 & -0.9 \\
\hline 2001 & 765 & 123.0 & 27 & 4.1 & 2.5 & 18.8 \\
\hline 2002 & 883 & 110.5 & 23 & 15.4 & 3.6 & -16.6 \\
\hline 2003 & 939 & 108.5 & 24 & 6.3 & 4.5 & 1.1 \\
\hline 2004 & 997 & 105.4 & 26 & 6.2 & 3.2 & 27.2 \\
\hline $2005^{\mathrm{a}}$ & 763 & 128.5 & 40 & & & \\
\hline Average & & 123.3 & 26 & 6.2 & 1.9 & 6.1 \\
\hline
\end{tabular}

Note: ${ }^{\mathrm{a}}$ The low number firms in 2005 resulted from the statistics office decision to take samples in specific sectors, such as bakery products, furniture, and manufacture of articles of concrete, cement, and plaster. The total population of formal manufacturing establishments in 2005 is above 1100 . 
Table 3: Export participation and per cent of exports in total production, plus employment, output, and export-shares by industry, 1996-2005

Export participation and \% of exports to total production value (average 1996-2005)

Employment, output, and export-shares by $\%$ of exports to industry $(\%)$

\begin{tabular}{|c|c|c|c|c|c|c|c|c|c|}
\hline \multirow[b]{2}{*}{ Industry } & \multirow{2}{*}{$\begin{array}{c}\% \text { of } \\
\text { firms } \\
\text { exporting } \\
\end{array}$} & \multicolumn{2}{|c|}{$\begin{array}{c}\% \text { of exports to } \\
\text { total production } \\
\text { value } \\
\end{array}$} & \multicolumn{2}{|c|}{ Employment } & \multicolumn{2}{|c|}{ Output } & \multicolumn{2}{|c|}{ Export } \\
\hline & & $\begin{array}{c}\text { All } \\
\text { firms }\end{array}$ & $\begin{array}{l}\text { Exporting } \\
\text { firms } \\
\end{array}$ & 1996 & 2004 & 1996 & 2004 & 1996 & 2004 \\
\hline Food & 3.05 & 5.7 & 15.7 & 17.52 & 20.52 & 21.82 & 23.17 & 2.92 & 16.62 \\
\hline Beverages & 16.05 & 1.4 & 6.1 & 8.50 & 9.21 & 15.05 & 13.78 & 0.05 & 0.23 \\
\hline Textiles & 18.02 & 8.3 & 19.4 & 31.17 & 21.80 & 11.16 & 9.07 & 4.24 & 14.44 \\
\hline Apparel & 8.73 & 2.4 & 11.4 & 4.50 & 3.59 & 2.15 & 0.73 & 0.92 & 0.13 \\
\hline Leathe & 97.10 & 80.4 & 81.2 & 3.96 & 3.45 & 3.22 & 5.58 & 91.27 & 68.26 \\
\hline Footwear & 3.53 & 2.2 & 16.9 & 4.66 & 3.76 & 1.10 & 1.92 & 0.06 & 0.18 \\
\hline Subtotal & 9.78 & & & 70.31 & 62.32 & 54.51 & 54.25 & 99.46 & 99.86 \\
\hline $\begin{array}{l}\text { All other } \\
\text { industries }\end{array}$ & 0.68 & & & 29.69 & 37.68 & 45.49 & 45.75 & 0.54 & 0.14 \\
\hline Total & 4.6 & 7.7 & 31.8 & 100 & 100 & 100 & 100 & 100 & 100 \\
\hline
\end{tabular}


Table 4: Characteristics of exporting and non-exporting firms, by industry, 1996-2005

\begin{tabular}{|c|c|c|c|c|c|c|}
\hline & Export status & $\begin{array}{c}\text { Number of } \\
\text { workers }\end{array}$ & $\begin{array}{l}\text { average } \\
\text { wage of } \\
\text { production } \\
\text { workers }\end{array}$ & $\begin{array}{c}\text { average } \\
\text { wage of non- } \\
\text { production } \\
\text { workers }\end{array}$ & $\begin{array}{c}\text { output per } \\
\text { worker }\end{array}$ & $\begin{array}{c}\text { capital per } \\
\text { worker }\end{array}$ \\
\hline \multirow[t]{3}{*}{ Food } & non-exporting & 98.7 & 4079.1 & 5416.5 & 85472.3 & 73760.9 \\
\hline & exporting & 836.6 & 8121.7 & 9774.6 & 110460.1 & 110542.5 \\
\hline & All & 138.6 & 4308.9 & 5678.1 & 86832.1 & 75751.7 \\
\hline \multirow[t]{3}{*}{ Beverage } & non-exporting & 342.0 & 6165.6 & 8708.9 & 112556.3 & 80562.5 \\
\hline & exporting & 585.6 & 9520.7 & 10991.3 & 141862.4 & 109299.0 \\
\hline & All & 381.0 & 6694.7 & 9078.3 & 117298.8 & 85174.5 \\
\hline \multirow[t]{3}{*}{ Textile } & non-exporting & 577.0 & 3789.8 & 5521.2 & 52873.1 & 30680.6 \\
\hline & exporting & 1285.0 & 5376.1 & 7750.8 & 77654.1 & 58335.7 \\
\hline & All & 704.6 & 4081.7 & 5958.7 & 57378.7 & 35664.9 \\
\hline \multirow[t]{3}{*}{ Apparel } & non-exporting & 131.8 & 3583.8 & 4799.1 & 36732.8 & 23659.8 \\
\hline & exporting & 230.6 & 4080.8 & 5858.2 & 44240.8 & 19719.0 \\
\hline & All & 140.4 & 3629.6 & 4901.8 & 37400.1 & 23315.9 \\
\hline \multirow[t]{3}{*}{ Leather } & non-exporting & 102.5 & 10521.0 & 12746.0 & 58966.9 & - \\
\hline & exporting & 265.5 & 6042.8 & 9369.0 & 138844.9 & 67793.5 \\
\hline & All & 260.7 & 6173.5 & 9466.8 & 136529.6 & 99348.6 \\
\hline \multirow[t]{3}{*}{ Footwear } & non-exporting & 80.2 & 3200.2 & 5828.3 & 42901.1 & 95457.1 \\
\hline & exporting & 321.9 & 6343.3 & 8886.6 & 41186.5 & 60531.3 \\
\hline & All & 88.8 & 3317.2 & 5952.0 & 42840.6 & 94224.4 \\
\hline \multicolumn{7}{|c|}{ all six industries } \\
\hline \multirow[t]{3}{*}{ Mean } & non-exporting & 182.2 & 4037.5 & 5787.0 & 70399.9 & 69186.3 \\
\hline & exporting & 595.4 & 6568.5 & 9068.7 & 111552.4 & 74911.2 \\
\hline & $\begin{array}{l}\text { proportion } \\
\text { exporter/non- } \\
\text { exporter }\end{array}$ & 3.3 & 1.6 & 1.6 & 1.6 & 1.1 \\
\hline \multirow[t]{3}{*}{ Median } & non-exporting & 36 & 3214.7 & 4900 & 36276.2 & 25342.1 \\
\hline & Exporting & 311 & 5379.5 & 8253.3 & 75579.0 & 35154.1 \\
\hline & $\begin{array}{l}\text { proportion } \\
\text { exporter/non- } \\
\text { exporter }\end{array}$ & 8.6 & 1.7 & 1.7 & 2.1 & 1.4 \\
\hline \multirow[t]{2}{*}{ N } & non-exporting & 2217 & 2118 & 1985 & 2201 & 2217 \\
\hline & Exporting & 335 & 333 & 334 & 335 & 334 \\
\hline
\end{tabular}


Table 5: Probit estimation of export premia

\begin{tabular}{|c|c|c|c|c|c|}
\hline $\begin{array}{l}\text { Dependent variable } \\
\text { exporter dummy } \\
\text { (export=1 if at current year) }\end{array}$ & $\begin{array}{c}\text { No control } \\
\text { Coef. } \\
\text { (sd) }\end{array}$ & $\begin{array}{c}\text { industry } \\
\text { controlled } \\
\text { Coef. } \\
(\mathrm{sd})\end{array}$ & $\begin{array}{c}\text { industry and } \\
\text { year } \\
\text { controlled } \\
\begin{array}{c}\text { Coef. } \\
\text { (sd) }\end{array} \\
\end{array}$ & $\begin{array}{c}\text { industry, } \\
\text { year and } \\
\text { size } \\
\text { controlled } \\
\text { Coef. } \\
\text { (sd) } \\
\end{array}$ & $\mathrm{N}$ \\
\hline In(Labor) & $\begin{array}{l}0.41^{* * *} \\
(0.023)\end{array}$ & $\begin{array}{l}0.44^{* * *} \\
(0.032)\end{array}$ & $\begin{array}{l}0.45^{\star \star \star} \\
(0.033)\end{array}$ & & 2552 \\
\hline In(Capital/Labor) & $\begin{array}{l}0.32^{* * *} \\
(0.021)\end{array}$ & $\begin{array}{l}0.29^{\star * *} \\
(0.025)\end{array}$ & $\begin{array}{l}0.29^{\star \star \star} \\
(0.025)\end{array}$ & $\begin{array}{l}0.12^{\star \star \star} \\
(0.031)\end{array}$ & 2530 \\
\hline $\begin{array}{l}\text { In(wage/Labor) } \\
\text { production workers }\end{array}$ & $\begin{array}{l}0.74^{\star \star \star} \\
(0.056)\end{array}$ & $\begin{array}{l}0.68^{\star \star *} \\
(0.068)\end{array}$ & $\begin{array}{l}0.69^{\star \star \star} \\
(0.071)\end{array}$ & $\begin{array}{l}0.33^{\star \star \star} \\
(0.084)\end{array}$ & 2442 \\
\hline $\begin{array}{l}\text { In(wage/Labor) } \\
\text { non-pro workers }\end{array}$ & $\begin{array}{l}0.74^{\star \star \star} \\
(0.057)\end{array}$ & $\begin{array}{l}0.61^{\star * *} \\
(0.067)\end{array}$ & $\begin{array}{l}0.62^{\star \star *} \\
(0.070)\end{array}$ & $\begin{array}{l}0.35^{\star * \star} \\
(0.083)\end{array}$ & 2310 \\
\hline In(labor cost/output) & $\begin{array}{l}-0.41^{* *} \\
(0.178)\end{array}$ & $\begin{array}{c}-0.29 \\
(0.193)\end{array}$ & $\begin{array}{l}-0.321^{*} \\
(0.196)\end{array}$ & $\begin{array}{l}-0.66^{\star \star \star} \\
(0.217)\end{array}$ & 2518 \\
\hline In(Output/Labor) & $\begin{array}{l}0.31^{\star \star \star} \\
(0.030)\end{array}$ & $\begin{array}{l}0.23^{\star \star \star} \\
(0.035)\end{array}$ & $\begin{array}{l}0.23^{* \star *} \\
(0.036)\end{array}$ & $\begin{array}{l}0.22^{\star \star \star} \\
(0.042)\end{array}$ & 2518 \\
\hline In(Value added/Labor) & $\begin{array}{l}0.25^{\star \star \star} \\
(0.028)\end{array}$ & $\begin{array}{l}0.25^{\star \star \star} \\
(0.034)\end{array}$ & $\begin{array}{l}0.27^{\star \star \star} \\
(0.035)\end{array}$ & $\begin{array}{l}0.21^{\star \star \star} \\
(0.040)\end{array}$ & 2094 \\
\hline InTFP & $\begin{array}{l}0.227^{\star \star \star} \\
(0.0306)\end{array}$ & $\begin{array}{l}0.167^{\star \star} \\
(0.073)\end{array}$ & $\begin{array}{c}0.195^{\star \star \star} \\
(0.076)\end{array}$ & $\begin{array}{c}0.280^{\star \star \star} \\
(0.084)\end{array}$ & 2486 \\
\hline
\end{tabular}

***, $* *$, and $*$ represent $1 \%, 5 \%$, and $10 \%$ levels of significance respectively. 
Table 6: System GMM results on exports and productivity

\begin{tabular}{|c|c|c|c|}
\hline \multirow[b]{2}{*}{ Dependent variable In(output) } & \multicolumn{2}{|c|}{ All observations } & \multirow{2}{*}{$\begin{array}{l}\text { The matched } \\
\text { sample } \\
\begin{array}{c}\text { Coef. } \\
\text { (sd) }\end{array}\end{array}$} \\
\hline & $\begin{array}{l}\text { Coef. } \\
\text { (sd) }\end{array}$ & $\begin{array}{c}\text { Coef. } \\
\text { (sd) }\end{array}$ & \\
\hline $\ln (\text { output })_{(\mathrm{t}-1)}$ & $\begin{array}{l}0.14^{\star \star \star} \\
(0.034)\end{array}$ & $\begin{array}{l}0.11^{* * *} \\
(0.033)\end{array}$ & $\begin{array}{c}0.023 \\
(0.046)\end{array}$ \\
\hline In(capital) & $\begin{array}{l}-0.05 \\
(0.082)\end{array}$ & $\begin{array}{c}-0.02 \\
(0.060)\end{array}$ & $\begin{array}{c}0.150 \\
(0.116)\end{array}$ \\
\hline In(labor) & $\begin{array}{l}0.20^{\star * \star} \\
(0.059)\end{array}$ & $\begin{array}{l}0.16^{\star \star \star} \\
(0.060)\end{array}$ & $\begin{array}{c}0.175 \\
(0.236)\end{array}$ \\
\hline In(intermediate) & $\begin{array}{l}0.86^{\star \star \star} \\
(0.060)\end{array}$ & $\begin{array}{l}0.84^{\star \star \star} \\
(0.055)\end{array}$ & $\begin{array}{l}0.814^{\star \star \star} \\
(0.122)\end{array}$ \\
\hline Export $_{(t-1)}$ & $\begin{array}{l}0.15^{\star *} \\
(0.076)\end{array}$ & $\begin{array}{c}0.17^{\star} \\
(0.098)\end{array}$ & $\begin{array}{l}0.324^{\star *} \\
(0.163)\end{array}$ \\
\hline$\#$ of years since export $(t-1)$ & & $\begin{array}{c}0.02 \\
(0.020)\end{array}$ & $\begin{array}{l}0.056^{*} \\
(0.034)\end{array}$ \\
\hline $\ln (\text { age })_{(t-1)}$ & & $\begin{array}{l}-0.05 \\
(0.053)\end{array}$ & $\begin{array}{c}0.041 \\
(0.161)\end{array}$ \\
\hline _cons & $\begin{array}{c}0.46 \\
(1.322)\end{array}$ & $\begin{array}{c}0.86 \\
(1.146)\end{array}$ & $\begin{array}{l}-0.362 \\
(2.373)\end{array}$ \\
\hline year controlled & Yes & Yes & Yes \\
\hline industry controlled & Yes & Yes & Yes \\
\hline Number of observations & 1828 & 1828 & 654 \\
\hline $\begin{array}{l}\text { Number of firms } \\
\text { p-values }\end{array}$ & 425 & 425 & 195 \\
\hline $\operatorname{AR}(1)$ & 0.0 & 0.0 & 0.00 \\
\hline $\operatorname{AR}(2)$ & 0.215 & 0.141 & 0.133 \\
\hline Hansen & 0.159 & 0.164 & 0.270 \\
\hline
\end{tabular}

The instruments for the differenced equation in the first two columns are $1^{\text {st }}$ lag and earlier for the inputs and $2^{\text {nd }}$ lag and earlier for output and other explanatory variables. In the third column (in the matched sample) all are second lag and earlier except the raw material. On the other hand, only lagged first differences are used as instruments for the level equations. The standard errors are robust finite sample corrected on two-step estimates derived from Windmeijer (2000). The Hansen test of the overidentifying restriction is a minimized value of the two-step GMM criterion function and robust to heteroscedasticity or autocorrelation and the null is that the instruments are valid. The serial correlation test is also reported as $\mathrm{AR}(1)$ and $\mathrm{AR}(2)$ under the null of no serial correlation. We only report the pvalues of these different tests. ${ }^{* * *},{ }^{* *}$, and $*$ represent $1 \%, 5 \%$. And $10 \%$ levels of significance respectively. 
Figure 1: Patterns of TFP, labor productivity and unit labor-cost, by export history

Figure 1a path of TFP of entrant and never export firms

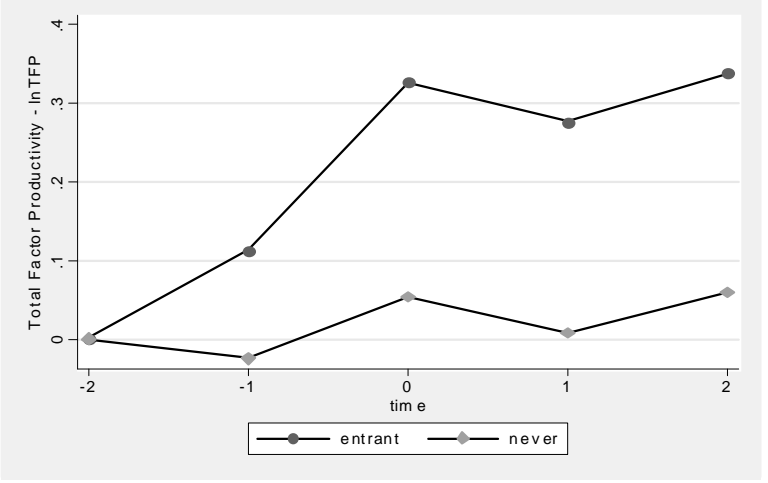

Figure $1 \mathrm{~b}$ path of labor productivity $(\mathrm{Q} / \mathrm{L})$ of entrant and never export firms

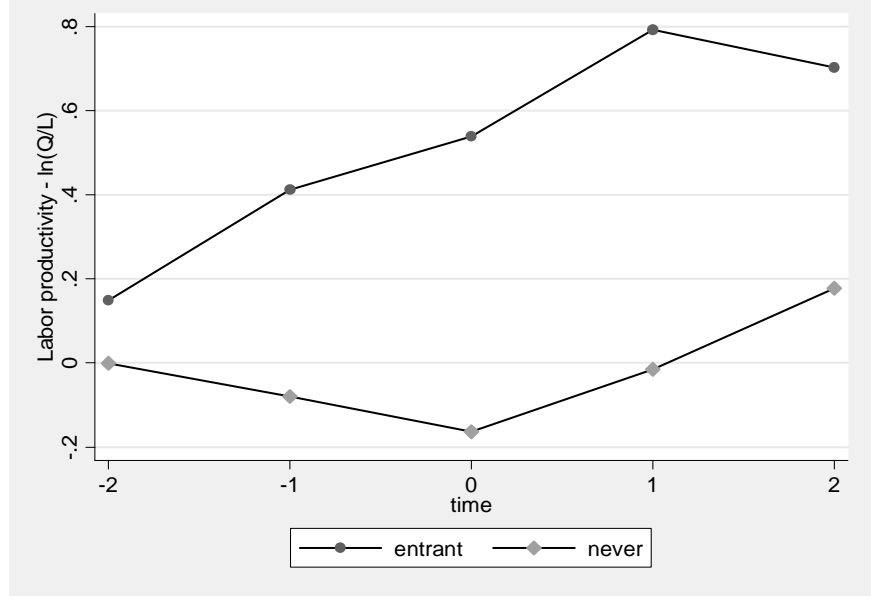

Figure 1c path of labor cost per output (ULC) of entrant and never export firms

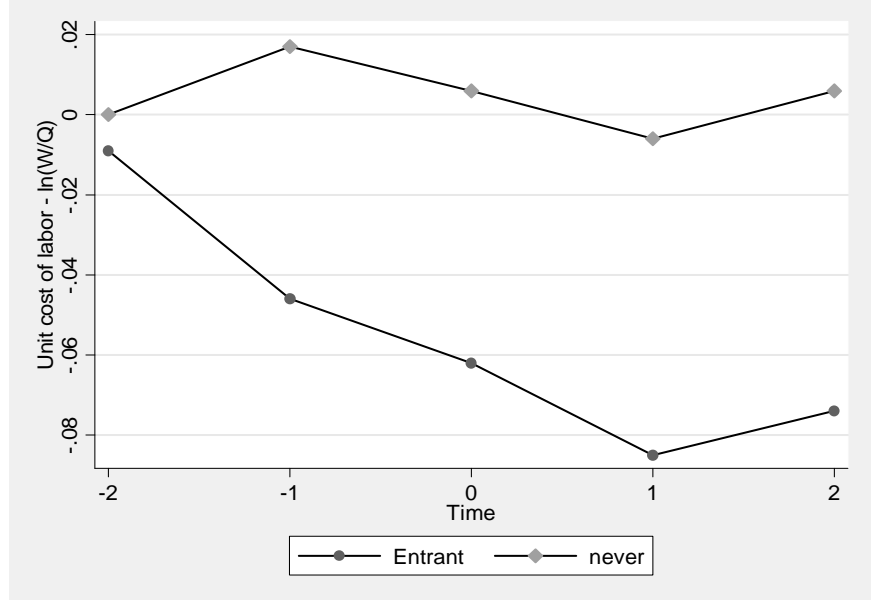


Figure 2: Patterns of sales, employment and investment by export group

Figure 2a relative level of sales of entrant and never exporters

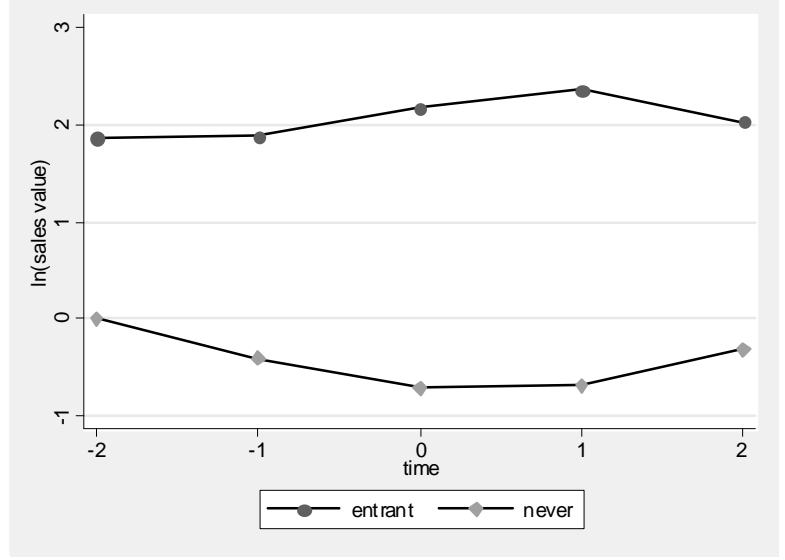

Figure $2 \mathrm{~b}$ relative level of employment of entrant and never exporters

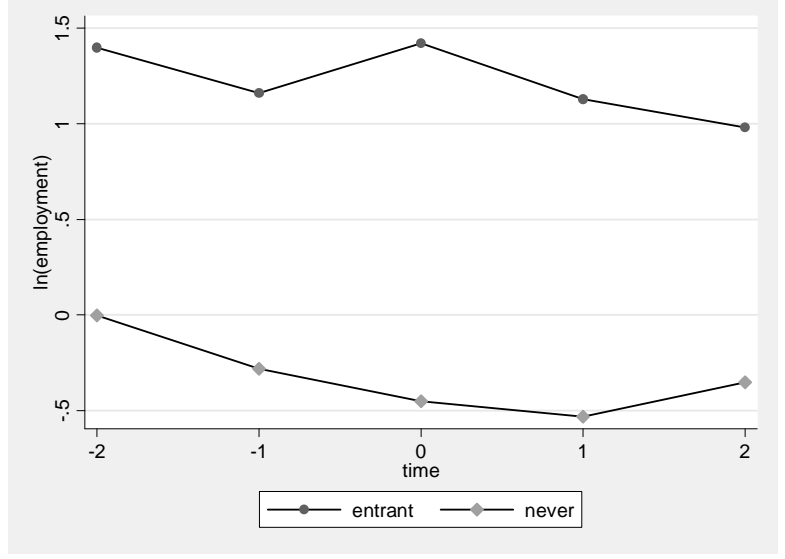

Figure 2c relative level of investment of entrant and never exporters

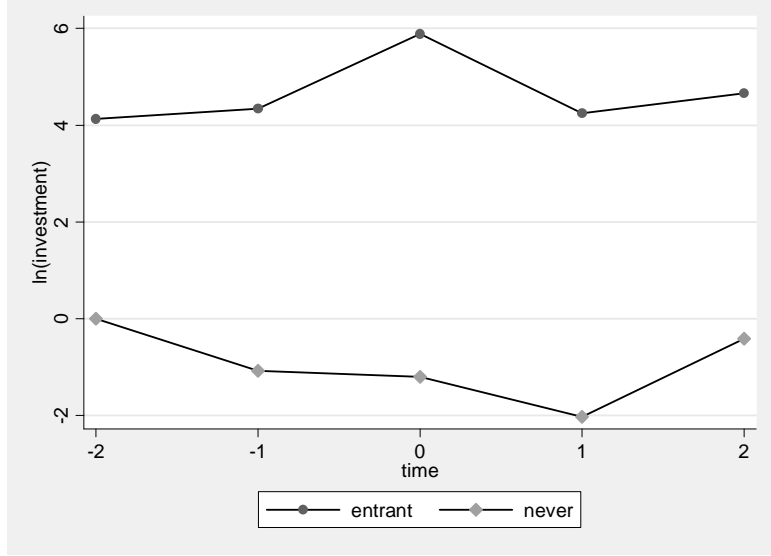




\section{Appendix A: Estimation of the production function}

Following Blundel and Bond (1998), was derived from a residual of the estimation of a production function of a Cobb Douglas form (see Equation 4 in the main text) using system-GMM.

Table A1 reports the estimation results by sector: food and beverages; textiles and apparel; and leather and footwear. We test Hansen-Difference for food/beverage between different models the default which use full set of lagged instruments (first lag and early for the transformed equation and zero lag for the level equation) the validity of the instrument can not be rejected in comparison to nested models such as 2-lags and earlier, only first lag. Thus the reported coefficients for the food \& beverages sector are based on instruments of the first and early lags. For Textiles \& apparel and leather \& footwear, the full set of instruments and even second-lag and earlier appeared to be over-rifting the estimation, as indicated by the Hansen overidentification test-statistic equal to one. This might be because of the small number of observations with too many instruments. We therefore only took the first lag as instrument, which was acceptable by the different tests. For comparison purpose we have also reported the OLS estimation results.

\section{Table A1 Production function estimation results by industry}

\begin{tabular}{|c|c|c|c|c|c|c|}
\hline & \multicolumn{2}{|c|}{ Food and Beverage } & \multicolumn{2}{|c|}{ Textile and apparel } & \multicolumn{2}{|c|}{ Leather and footwear } \\
\hline & OLS & GMM & OLS & GMM & OLS & GMM \\
\hline & $\begin{array}{l}\text { Coef. } \\
\text { (se.) }\end{array}$ & $\begin{array}{l}\text { Coef. } \\
\text { (se.) }\end{array}$ & $\begin{array}{l}\text { Coef. } \\
\text { (se.) }\end{array}$ & $\begin{array}{l}\text { Coef. } \\
\text { (se.) }\end{array}$ & $\begin{array}{l}\text { Coef. } \\
\text { (se.) }\end{array}$ & $\begin{array}{l}\text { Coef. } \\
\text { (se.) }\end{array}$ \\
\hline Capital & $\begin{array}{l}0.037^{\star \star *} \\
(0.008)\end{array}$ & $\begin{array}{l}0.017 \\
(0.027)\end{array}$ & $\begin{array}{l}0.030 \star \star \star \\
(0.010)\end{array}$ & $\begin{array}{l}0.010 \\
(0.019)\end{array}$ & $\begin{array}{l}0.017^{\star} \\
(0.010)\end{array}$ & $\begin{array}{l}0.075^{\star \star} \\
(0.035)\end{array}$ \\
\hline Labor & $\begin{array}{l}0.242^{\star \star *} \\
(0.014)\end{array}$ & $\begin{array}{l}0.213^{\star \star *} \\
(0.044)\end{array}$ & $\begin{array}{l}0.074^{\star \star *} \\
(0.023)\end{array}$ & $\begin{array}{l}0.164^{\star *} \\
(0.082)\end{array}$ & $\begin{array}{l}0.160^{* \star *} \\
(0.019)\end{array}$ & $\begin{array}{l}0.196^{\star \star *} \\
(0.057)\end{array}$ \\
\hline Intermediate Inputs & $\begin{array}{l}0.876^{\star \star *} \\
(0.011)\end{array}$ & $\begin{array}{l}0.932^{\star \star \star} \\
(0.031)\end{array}$ & $\begin{array}{l}0.831^{\star \star \star} \\
(0.018)\end{array}$ & $\begin{array}{l}0.817^{\star \star \star} \\
(0.041)\end{array}$ & $\begin{array}{l}0.829^{\star \star \star \star} \\
(0.014)\end{array}$ & $\begin{array}{l}0.773^{\star \star \star} \\
(0.035)\end{array}$ \\
\hline year controlled & yes & yes & yes & yes & yes & yes \\
\hline N & 1343 & 1343 & 591 & 591 & 552 & 552 \\
\hline$A R(1) p$-value & & 0.000 & & 0.00 & & 0.000 \\
\hline AR(2) p-value & & 0.917 & & 0.205 & & 0.815 \\
\hline Hansen test (p-value) & & 0.333 & & 0.340 & & 0.295 \\
\hline
\end{tabular}

Notes: The standard errors are robust finite sample corrected on two-step estimates derived from Windmeijer (2000). The Hansen test of the over-identifying restriction is a minimized value of the twostep GMM criterion function, robust to hetersoedasticity or autocorrelation; the null is that the instruments are valid. $* * *, * *$, and $*$ represent one, five and ten percent levels of significance respectively. 
Appendix B: Additional tables

Table B1: Patterns of TFP, labor productivity, and labor-cost per unit

\begin{tabular}{|c|c|c|c|c|c|}
\hline & & \multicolumn{4}{|c|}{ Firm export history group } \\
\hline Variable & Firm location & Entrant & always & switcher & never \\
\hline \multirow{10}{*}{$\ln (\mathrm{TFP})$} & -2 & 0.001 & -0.022 & 0.097 & 0.0 \\
\hline & & $(0.01)$ & $(0.16)$ & $(1.08)$ & $(0.0)$ \\
\hline & -1 & 0.114 & 0.341 & 0.164 & -0.024 \\
\hline & & $(1.02)$ & $(2.55)^{* *}$ & $(1.77)^{*}$ & $(0.56)$ \\
\hline & 0 & 0.327 & 0.414 & 0.143 & 0.054 \\
\hline & & $(3.78)^{* * *}$ & $(3.06)^{* * *}$ & $(1.79)^{*}$ & $(1.41)$ \\
\hline & 1 & 0.277 & 0.084 & -0.041 & 0.008 \\
\hline & & $(2.83) * * *$ & $(0.62)$ & $(0.47)$ & $(0.20)$ \\
\hline & 2 & 0.339 & 0.023 & 0.021 & 0.060 \\
\hline & & $(3.17)^{* * *}$ & $(0.16)$ & $(0.22)$ & $(1.12)$ \\
\hline \multirow{10}{*}{$\ln (\mathrm{Q} / \mathrm{L})$} & -2 & 0.149 & 0.139 & -0.265 & 0.00 \\
\hline & & $(0.46)$ & $(0.39)$ & $(1.13)$ & 0.00 \\
\hline & -1 & 0.413 & 0.380 & -0.344 & -0.080 \\
\hline & & $(1.41)$ & $(1.08)$ & $(1.42)$ & $(0.72)$ \\
\hline & 0 & 0.540 & 0.182 & -0.309 & -0.163 \\
\hline & & $(2.38)^{* *}$ & $(0.51)$ & $(1.48)$ & $(1.63)$ \\
\hline & 1 & 0.793 & 0.051 & -0.540 & -0.015 \\
\hline & & $(3.09) * * *$ & $(0.14)$ & $(2.38)^{* *}$ & $(0.14)$ \\
\hline & 2 & 0.704 & 0.265 & -0.095 & 0.178 \\
\hline & & $(2.51)^{* *}$ & $(0.71)$ & $(0.38)$ & $(1.27)$ \\
\hline \multirow[t]{10}{*}{$\ln (\mathrm{ULC})$} & -2 & -0.009 & -0.072 & -0.031 & 0.00 \\
\hline & & $(0.20)$ & $(1.41)$ & $(0.95)$ & 0.00 \\
\hline & -1 & -0.046 & -0.071 & -0.019 & 0.017 \\
\hline & & $(1.06)$ & $(1.43)$ & $(0.56)$ & $(1.04)$ \\
\hline & 0 & -0.062 & -0.067 & 0.002 & 0.006 \\
\hline & & $(1.83)^{*}$ & $(1.33)$ & $(0.07)$ & $(0.39)$ \\
\hline & 1 & -0.085 & -0.032 & 0.110 & -0.006 \\
\hline & & $(2.16)^{* *}$ & $(0.63)$ & $(3.40) * * *$ & $(0.39)$ \\
\hline & 2 & -0.074 & -0.062 & 0.002 & 0.006 \\
\hline & & $(1.80)^{*}$ & $(1.18)$ & $(0.04)$ & $(0.29)$ \\
\hline
\end{tabular}

Notes: The control group consists of firms that never exported at period (-2). In all estimations we controlled year and industry, while for TFP size was also controlled. Value in parentheses are tstatistics; $*$ significant at $10 \%, * *$ significant at $5 \%$; and $* * *$ significant at $1 \%$. 
Table B2: Paths of employment, investment, and sales, by export history group

\begin{tabular}{|c|c|c|c|c|c|}
\hline \multirow[b]{2}{*}{ Variable } & \multirow[b]{2}{*}{$\begin{array}{c}\text { Firm } \\
\text { location }\end{array}$} & \multicolumn{4}{|c|}{ Firm export history group } \\
\hline & & Entrant & Always & switcher & never \\
\hline \multirow{10}{*}{ ln(employment) } & -2 & 1.398 & 2.063 & 1.612 & 0.0 \\
\hline & & $(4.63)^{* * *}$ & $(5.99) * * *$ & $(7.32)^{* * *}$ & $(0.0)$ \\
\hline & -1 & 1.164 & 1.885 & 1.443 & -0.279 \\
\hline & & $(4.23)^{* * *}$ & $(5.59) * * *$ & $(6.65)^{* * *}$ & $(2.73) * * *$ \\
\hline & 0 & 1.415 & 1.644 & 1.298 & -0.449 \\
\hline & & $(6.63)^{* * *}$ & $(4.82) * * *$ & $(6.82)^{* * *}$ & $(4.90) * * *$ \\
\hline & 1 & 1.132 & 1.594 & 1.285 & -0.531 \\
\hline & & $(4.69)^{* * *}$ & $(4.67) * * *$ & $(6.17)^{* * *}$ & $(5.35)^{* * *}$ \\
\hline & 2 & 0.984 & 1.752 & 1.095 & -0.354 \\
\hline & & $(3.74) * * *$ & $(4.89) * * *$ & $(4.68) * * *$ & $(2.76) * * *$ \\
\hline \multirow{10}{*}{$\ln$ (investment) } & -2 & 4.133 & 8.514 & 3.686 & 0.0 \\
\hline & & $(2.49)^{* *}$ & $(4.50)^{* * *}$ & $(3.05)^{* * *}$ & $(0.0)$ \\
\hline & -1 & 4.339 & 7.880 & 2.779 & -1.072 \\
\hline & & $(2.87)^{* * *}$ & $(4.25) * * *$ & $(2.33) * *$ & $(1.91)^{*}$ \\
\hline & 0 & 5.893 & 6.740 & 2.612 & -1.198 \\
\hline & & $(5.02) * * *$ & $(3.59) * * *$ & $(2.50) * *$ & $(2.38)^{* *}$ \\
\hline & 1 & 4.245 & 6.568 & 0.866 & -2.018 \\
\hline & & $(3.20) * * *$ & $(3.50)^{* * *}$ & $(0.76)$ & $(3.70)^{* * *}$ \\
\hline & 2 & 4.662 & 6.239 & 2.952 & -0.408 \\
\hline & & $(3.23)^{* * *}$ & $(3.17)^{* * *}$ & $(2.30)^{* *}$ & $(0.58)$ \\
\hline \multirow{10}{*}{$\ln$ (sales) } & -2 & 1.858 & 2.694 & 1.751 & 0.0 \\
\hline & & $(3.80) * * *$ & $(4.83) * * *$ & $(4.91)^{* * *}$ & $(0.0)$ \\
\hline & -1 & 1.876 & 2.742 & 1.654 & -0.413 \\
\hline & & $(4.21)^{* * *}$ & $(5.02)^{* * *}$ & $(4.63)^{* * *}$ & $(2.47)^{* *}$ \\
\hline & 0 & 2.167 & 2.353 & 1.491 & -0.711 \\
\hline & & $(6.27)^{* * *}$ & $(4.25)^{* * *}$ & $(4.73)^{* * *}$ & $(4.77)^{* * *}$ \\
\hline & 1 & 2.362 & 2.084 & 1.066 & -0.687 \\
\hline & & $(6.04) * * *$ & $(3.77) * * *$ & $(3.16) * * *$ & $(4.25) * * *$ \\
\hline & 2 & 2.030 & 2.528 & 1.220 & -0.307 \\
\hline & & $(4.76) * * *$ & $(4.36) * * *$ & $(3.21)^{* * *}$ & $(1.47)$ \\
\hline
\end{tabular}

Note: The control group is never export at period (-2). In all estimations we controlled year and industry, and for the TFP estimation size was also controlled. The value in parentheses are t-statistics, $*$ significant at $10 \%, * *$ significant at $5 \%$; and $* * *$ significant at $1 \%$. 
Table B3: Logistic estimation results of the export participation equation

Dependent variable:

export dummy

Coef.

$0.72^{\star \star \star}$

$1.30 * \star *$

$-0.32^{\star * *}$

$0.15^{\star}$

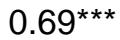

0.32

$-0.10$

$0.58^{*}$

$6.38^{\star \star *}$

$-0.13$

$-10.16^{\star * *}$

controlled

1894

Note that $*$ denotes significant at $10 \%,{ }^{* *}$ significant at $5 \%$; and $* * *$ significant at $1 \%$.

Table B4: Psmatch2 results on the difference between exporters and nonexporters

\begin{tabular}{|l|l|r|r|r|r|r|}
\hline Variable & Sample & \multicolumn{1}{l|}{ Treated } & \multicolumn{1}{l|}{ Controls } & Difference & \multicolumn{1}{l|}{ S.E. } & \multicolumn{1}{|c|}{ T-stat } \\
\hline & & & & & & \\
\hline TFP & Unmatched & 1.474 & 1.048 & 0.426 & 0.067 & 6.30 \\
\hline & ATT & 1.477 & 1.044 & 0.432 & 0.201 & 2.12 \\
\hline
\end{tabular}

